\title{
Risicomanagement, interne controle en de kredietschandalen
}

\section{Ruud Pruijm}

SAMENVATTING Als gevolg van nieuwe wetgeving zoals Sarbanes-Oxley en gedragscodes als die van de commissie Tabaksblat is het de expliciete verantwoordelijkheid van de directie om te zorgen voor een adequaat en effectief risicomanagement en intern beheersingssysteem. Het is opvallend dat deze nieuwe interne-controlevereisten de kredietcrisis niet hebben kunnen voorkomen in een zo streng gereguleerde bedrijfstak als die van de financiële dienstverlening. Ook de grote fraudes bij Société Générale en Caisse d'Epargne wijzen er op dat er op het gebied van de interne controle nog heel wat valt te verbeteren.

De grote vraag is dan ook hoe dit allemaal heeft kunnen gebeuren en welke mogelijke lessen er te trekken zijn.

\section{RELEVANTIE VOOR DE PRAKTIJK De verklaring van het management dat de interne risicobeheersings- en controlesystemen adequaat en effectief zijn is een belangrijke voor- waarde voor het vertrouwen van het publiek in een eerlijke, integere en transparante gang van zaken bij beursgenoteerde vennootschappen. Dat er ondanks deze verklaringen toch grote deconfitures hebben kunnen plaatsvinden roept op zijn minst twijfel op over de waar- borgen die een dergelijke verklaring in de praktijk geeft.}

\footnotetext{
1 Inleiding

Tot en met 28 januari 2009 is er volgens het Internationale Monetaire Fonds (IMF) wereldwijd 792 miljard dollar verdampt aan slechte kredieten. De banken hebben 826 miljard dollar bij overheden en beleggers opgehaald om de verslechterde balans weer een beetje op peil te brengen (IMF, 2009). De verliezen bij banken op slechte bezittingen zijn ongekend hoog en het zal nog jaren duren voordat deze verliezen weer zijn gecompenseerd. De laatste prognose van het IMF komt nu uit op een geschat verlies van 2.200 miljard dollar, terwijl dit eerder nog 1.400 miljard dollar was (IMF, 2009). Als gevolg van de problemen in de financiële sector hebben de aandelenmarkten in 2008 wereldwijd 30.000 miljard dollar verloren, waarvan alleen al in Amerika 7.200 miljard dollar (Sterngold, 2008).
}

Dat betekent dat de waarde van het bezit aan aandelen voor de aandeelhouders is gehalveerd. Het gevolg is dat zowel particuliere als zakelijke aandeelhouders (waaronder pensioenfondsen en andere institutionele beleggers zoals verzekeraars) enorme bedragen hebben verloren.

Vanuit economisch perspectief is er een enorme grote hoeveelheid geld verloren gegaan. Geld dat niet meer besteed kan worden aan allerlei zaken. Dat betekent dat er minder uitgegeven kan worden, door zowel bedrijven als particulieren. Het is daarom onontkoombaar dat de economie wereldwijd in elkaar zakt. Het zal de overheden zeer zwaar vallen om de economische machine weer op gang te brengen.

Het is in dit kader goed eens terug te kijken naar de verliezen van de boekhoudschandalen. Het totale verlies in marktwaarde van WorldCom, Tyco, Qwest, Enron en Global Crossing was $\$ 427$ miljard (Pruijm, 2003). Dat is een bedrag dat in het niet valt met het verlies aan marktwaarde van aandelen wereldwijd waar we nu mee te maken hebben van $\$ 30.000$ miljard.

Daarnaast is de reikwijdte van de huidige financiële crisis van een totaal andere orde.

Bij de boekhoudschandalen betrof het een relatief beperkt aantal ondernemingen uit verschillende sectoren van de economie. De verliezen door de boekhoudschandalen hadden dan ook geen gevolgen voor de gehele economie.

Het is nu juist specifiek de financiële sector die met enorme verliezen te kampen heeft en dat heeft zijn negatieve uitstraling op de andere sectoren in de economie. Niet alleen is de schade van de financiële crisis vele malen groter dan die van de boekhoudschandalen, maar ook de negatieve effecten op de economie zijn van een ongekende omvang.

\section{Wat waren de oorzaken?}

De hoorzittingen van de Amerikaanse Congres geven een goed beeld van de oorzaken van de financiële crisis (Hearings, 2008).

Een grote stijging in de kredietverlening, gebaseerd op de woningmarkt voor particulieren werd mogelijk gemaakt 
door innovaties in de financiële sector, de erosie van acceptatiestandaarden voor hypotheken en excessieve leverage van financiële instellingen.

Het sluiten in juni 2007 van twee hedgefunds van Bear Stearns die belegden in subprimehypotheken was het eerste teken van onheil. Naarmate het jaar vorderde kwamen steeds meer banken er achter dat deze beleggingen in snel tempo minder waard werden. Het instorten van de zakenbank Lehman Brothers in september 2008 was het begin van de financiële crisis, omdat in snel tempo de ene na de andere financiële instelling gedwongen werd om in hoog tempo verliezen te nemen waardoor het eigen vermogen verdampte.

Het veel te gemakkelijk geven van krediet was een belangrijke factor, daarbij geholpen door langdurig lage rentestanden. Dat dit mede op instignatie van de Amerikaanse overheid gebeurde droeg eveneens bij aan een stormachtige groei van het aantal verkochte hypotheken in Amerika.

De tweede factor was de securitisatie van hypotheken. Securitisatie is de overdracht, door een bank of een bedrijf, van bezittingen aan een speciaal daarvoor opgericht bedrijf (in het jargon een 'special investment vehicle' of SIV). Dit aparte bedrijf geeft verhandelbare effecten uit om de overname van de bezittingen te kunnen betalen, met genoemde bezittingen als een soort onderpand. In het Engels noemt men dit soort effecten 'asset-backed securities'. Hierdoor werd de liquiditeit van banken vergroot en het risico verspreid. Daarnaast waren deze SIV's een ideaal middel voor banken om riskante beleggingen buiten de balans te houden, zodat deze geen invloed hadden op hun verplichte kapitaalratio's.

Securitisatie gaf andere (internationale) spaarders de toegang tot een geheel nieuwe categorie van beleggingen en maakte tegelijkertijd het geven van kredieten aan particulieren en bedrijven goedkoop.

Door deze financiële innovaties raakte echter de band tussen kredietgever en kredietnemer verbroken met een aantal nadelige gevolgen. Het risico van een krediet kon gemakkelijk worden afgewenteld op een ander, waardoor de acceptatiestandaarden voortdurend werden verlaagd.

Securitisatie leidde echter tevens tot steeds complexere producten, die zelfs vaak niet meer door de directeuren van banken en toezichthouders begrepen werden. Voor een verdere bespreking van de 'donkere kant' van securitisatie verwijs ik naar het artikel van Vink in deze editie van MAB (Vink, 2009).

Soms werden hypotheken vier of vijf keer versneden en herverpakt gebaseerd op complexe statistische regels en ondoorzichtige waarderingsformules. Ook ontstonden er nog exotischer producten, zoals de inmiddels beruchte
Credit Default Swaps, waarvan het risico alleen nog met de ingewikkelde modellen van de Credit Rating Agencies was vast te stellen. Dat deze waardering niet altijd even objectief werd uitgevoerd was alleen binnen de kringen van Wall Street bekend.

Daarbij gingen de grote zaken- en retailbanken steeds meer lenen. Gemiddeld heeft een bank een 'leverage ratio' van ongeveer 4 tot 5 . Dat betekent dat de waarde van de schulden 4 tot 5 keer die van het eigen vermogen is. De zakenbanken werkten met een ratio van 30 tot 35 in de laatste paar jaar. Met dergelijk hoge ratio's is er geen buffer voor slechte tijden en kan men met relatief kleine verliezen in de kredietportefeuille in de problemen komen.

Eind 2006 raakte de huizenmarkt in Amerika verzadigd en ging de rente door inflatie omhoog. Al snel begonnen de verliezen op hypotheken zich op te stapelen, omdat huiseigenaren de rekening niet meer konden betalen. Saillant daarbij is dat in Amerika een huiseigenaar door het inleveren van de sleutel bij de bank direct van zijn schuld af is. De hypothecaire schuld is niet verbonden aan de persoon maar aan het bezit. Een dergelijke constructie is een eenzijdig gunstige optie voor de eigenaar en ongunstige optie voor de bank: waardestijgingen zijn voor de consument, waardedalingen kunnen worden overgedragen aan de bank.

In snel tempo werden de schuldpapieren op basis van hypotheken steeds minder waard en werden de subprimehypotheken 'giftig afval' in plaats van waardevolle bezittingen. Het vertrouwen in de financiële markten verdween en er ontstond een vicieuze cirkel van gedwongen verkoop van steeds minder waardevolle bezittingen, het afstoten van leningen ('deleveraging') en verslechterende condities om nog leningen te kunnen afsluiten. De zogeheten credit crunch was een feit en steeds meer banken raakten in de problemen.

Bezien we de kredietcrisis vanuit het oogpunt van interne beheersing dan zijn de COSO-componenten Risicobeoordeling en Beheersingskader van eminent belang (COSO, 1992/1994; 2009). De component risicobeheersing is van belang omdat het ontwerp van een effectief werkend systeem van interne beheersing gebaseerd dient te zijn op het goed onderkennen van de belangrijkste risico's. De component Beheersingskader omdat deze het fundament vormt voor de procesgeoriënteerde interne controles.

\section{Risicobeoordeling: Rendement boven risico?}

Voor alle financiële instellingen gold dat zij onderhevig waren aan de bekende vereisten van Sox-404. dan wel Tabaksblat of andere wetgeving voor wat betreft een adequaat en effectief werkend stelsel van interne risicobeheersings- en controlesystemen. In het jaarverslag dient 
daarover gerapporteerd te worden en voor in de Verenigde Staten genoteerde instellingen geldt bovendien dat de externe accountant toeziet op de juistheid van de uitgebrachte verklaring.

Het is opvallend dat bij vrijwel alle probleemgevallen die ik tot nu toe gezien heb het management in 2007 verklaarde dat op het gebied van interne beheersing de zaken in orde waren en dat de accountant dit oordeel onderstreepte, zoals te zien is in onderstaand overzicht.

Tabel 1 Verklaring over goed werkende interne beheersing

\begin{tabular}{|l|c|}
\hline & 2007 \\
\hline ABN Amro & ja \\
\hline Aegon & ja \\
\hline AlG & nee \\
\hline Bank of America & ja \\
\hline Barclays & ja \\
\hline Bear Stearns & ja \\
\hline Citigroup & ja \\
\hline Credit Suisse & nee \\
\hline Deutsche Bank & ja \\
\hline Goldman Sachs & ja \\
\hline HBOS & ja \\
\hline HSBC & ja \\
\hline ING & ja \\
\hline J. P. Morgan Chase & ja \\
\hline Lehman Brothers & ja \\
\hline Lloyds TSB Group & ja \\
\hline Merrill Lynch & ja \\
\hline Morgan Stanley & ja \\
\hline RBS & ja \\
\hline UBS & ja \\
\hline
\end{tabular}

De enige uitzonderingen die ik heb kunnen vinden zijn de jaarverslagen van Credit Suisse en AIG, waar door de directie een voorbehoud wordt gemaakt. Royal Bank of Scotland geeft weliswaar een positieve verklaring maar maakt een voorbehoud over de waardering van het overgenomen deel van ABN Amro.

Credit Suisse meldt in zijn jaarverslag:

'As of December 31. 2007, the controls over the valuation of $A B S$ positions in the $C D O$ trading business in Investment Banking relating to the supervision and monitoring of the initial valuations of these positions by trading personnel and the related price testing and supervision by product control, which is segregated from trading, were not effective. The Group's price testing of these positions included modeling techniques that failed to accurately value these positions. This resulted in adjustments to the Group's preliminary 2007 consolidated financial statements. As a result of this material weakness in internal control, management, including the Group CEO and CFO, has concluded that the Group's internal control over financial reporting was not effective as of December 31, $2007^{\prime}$ (Credit Suisse, 2009, p. 258).

AIG meldt in zijn jaarverslag:

'AIG did not maintain, in all material respects, effective internal control over financial reporting as of December 31, 2007, based on criteria established in Internal Control Integrated Framework issued by the Committee of Sponsoring Organizations of the Treadway Commission (COSO) because a material weakness in internal control over financial reporting related to the AIGFP super senior credit default swap portfolio valuation process and oversight thereof existed as of that date,' (AIG, 2007, p. 129; zie ook p. 202, 203).

Het betreft hier een kleine dochteronderneming, AIG Financial Products, die uiteindelijk verantwoordelijk bleek voor een verlies van 25 miljard dollar waardoor AIG staatssteun moest vragen om het te redden. Eerder al had The Office of Thrift Supervision geconstateerd dat er onvoldoende toezicht was door het management van AIG en dat sleutelfiguren van de risicomanagementafdeling geen of onvoldoende toegang kregen tot de gewenste informatie (zie ook Smeulders et al., 2009; dit themanummer van MAB, voor een uitgebreide bespreking van de AIG-casus).

Uit de hoorzitting blijkt dat er al eerder signalen waren gegeven aan het topmanagement van AIG dat er bij Financial Products bepaalde zaken niet klopten, maar daar werd niets mee gedaan. Bij AIG bleken voortdurend problemen te bestaan op het gebied van interne beheersing en risicomanagement.

De vraag waarom het management, het Audit Committee en de externe accountant dit zo lang op hun beloop lieten werd in de hoorzitting opvallend genoeg niet beantwoord. Saillant is ook dat intern accountant Joseph St. Denis gedwongen werd ontslag te nemen omdat hij van mening was dat hij zijn functie niet goed genoeg kon uitoefenen en door de hoogste leiding binnen AIG onder druk werd gezet om bepaalde controlehandelingen niet te doen, dan wel bevindingen niet te rapporteren (Committee on Oversight and Government Reform, Hearing AIG, 2008, p. 7 e.v.).

Een opvallende rol in dit overzicht wordt gespeeld door UBS omdat al snel na de publicatie van het jaarverslag 2007 bleek dat er op het gebied van interne controle het nodige aan de hand was. Naast een intern onderzoek naar de gang 
van zaken is er ook onderzoek gedaan door de Zwitserse Bankiersvereniging. Het onderzoeksrapport verklaart dat ... "UBS was not aware of the extent and the nature of its risk exposure to the Subprime mortgage and related markets until the beginning of August 2007, and was thus unable to take appropriate measures in a timely manner" (SFBC, 2008).

De commissie concludeert dat er onvoldoende aandacht was voor de inherente risico's die gepaard gaan met een sterke groei van de balans en het te veel vertrouwen stellen in de bestaande risicomanagement- en risicocontrolemechanismen. Vooral de risico's in de subprimehypotheken werden onvoldoende beheerst en goed ingeschat. Ofwel, de constatering van het management dat deze systemen adequaat en effectief waren is een onjuiste voorstelling van de gang van zaken.

Naar mijn mening kunnen we zonder meer concluderen dat de financiële instellingen allemaal min of meer op deze manier hebben gefaald. De enorme geleden verliezen zijn daarvan al een duidelijke indicatie, ook zonder dat er verder onderzoek naar is gedaan.

Het risicomanagement is duidelijk tekort geschoten, vooral voor de nieuwe financiële innovaties en dat juist in een categorie ondernemingen waar risicobeheer al van oudsher een van de kerncompetenties is.

De veelgebruikte verdediging van het topmanagement dat de kredietcrisis een niet te voorziene gebeurtenis was is dan ook volstrekt ongeloofwaardig. Eerder is er sprake geweest van onverantwoordelijk management om groei en winst na te jagen via allerlei financiële innovaties zonder daarbij de inherente risico's serieus te nemen, of zelfs bewust te negeren.

Het is in dit verband dan ook opvallend dat de Nederlandse verzekeraars de hand in eigen boezem steken en hun falen erkennen. Ik citeer: "Want achteraf bezien is de afgelopen jaren in het streven naar hoge rendementen in de hele keten onvoldoende oog geweest voor de onderliggende risico's" (Verbond van Verzekeraars, 2009).

De kredietcrisis was geen financiële tsunami die ons onverwacht is overkomen, maar een door de mens geschapen fiasco. De eerste voortekenen waren al slechts een paar jaar geleden waar te nemen en wereldkundig gemaakt door verschillende financiële deskundigen. In ons land was dat met name Jules Muis die op de Accountantsdag van 2004 al wees op de gevaren van derivaten en in de Verenigde Staten de bekende investeerder Warren Buffett in zijn bekende brieven van 2002 aan de aandeelhouders van Berkshire Hathaway.

Wat nog volstrekt onduidelijk is, is hoe men de risico's over het hoofd heeft kunnen zien. Hoe kan een risicomanager bij Citigroup in vijf jaar tijd een portefeuille CDO's zien groeien van een paar miljard tot dertig of veertig miljard euro en daar niet op reageren (Dash en Creswell, 2008)?

Het is gissen naar wat er daadwerkelijk gebeurde: of de risicomanager sprak zich niet uit, of er werd niet naar hem geluisterd.

Illustratief voor dit laatste is de gang van zaken bij de hypotheekbank Freddie Mac (Committee on Oversight and Government Reform, Hearing Fannie Mae en Freddie, 2008, p. 4, 5):

'In 2004, Freddie Mac's chief risk officer sent an e-mail to CEO Richard Syron urging Freddie Mac to stop purchasing loans with no income or asset requirements as soon as practicable. The risk officer warned that mortgage lenders were targeting borrowers who would have trouble qualifying for a mortgage if their financial position were adequately disclosed and that the, quote, "potential for the perception and the reality of predatory lending with this product is great." But Mr. Syron did not adopt the chief risk officer's recommendation. Instead, the company fired him.

A year later, on November 10, 2005, a top Fannie Mae official warned, quote, "Our conclusion has consistently been that the layering of risk in many of these privatelabel securities has not adequately been reflected in their pricing,' end quote.

On October 28, 2006, Fannie's chief risk officer sent an e-mail to company CEO Daniel Mudd warning about a serious problem at the company. He wrote, quote, "There is a pattern emerging of inadequate regard for the control process." end quote.'

Het management van Fannie Mae negeerde deze waarschuwingen echter en presenteerde aan de Board zelfs plannen om nog meer risico te nemen met het overnemen van steeds slechtere subprimehypotheken.

Hieruit blijkt dat van een risicomanager meer moet worden verwacht dan het begrijpen van en toezicht houden op risico's. Hij moet ook de bereidheid en onafhankelijkheid hebben om zijn boodschap te brengen, tot aan de hoogste niveaus in de organisatie. Van de leiding mag verwacht worden dat zij het vermogen hebben om het advies van de risicomanager te begrijpen en daarop te reageren (desnoods met drastische actie).

Fannie Mac en ook de gang van zaken bij AIG Financial Products laten zien dat de brenger van slecht nieuws niet werd gehoord maar onthoofd.

\section{Beheersingskader}

De COSO-component Beheersingskader (Control environment) is de basis voor alle andere elementen van interne beheersing. Factoren die de kwaliteit van het beheersingskader bepalen zijn onder meer: de integriteit, zakelijke ethiek en deskundigheid van medewerkers; de stijl van 
leidinggeven van het management; de wijze waarop bevoegdheden en verantwoordelijkheden door het management worden gedelegeerd, maar ook de inzet en ontwikkeling van personeel; de aandacht die de directie voor de onderneming heeft en de mate waarin zij er sturing aan geeft, de zogeheten 'Tone at the Top'.

In het kader van dit artikel wil ik niet alle factoren behandelen maar kort stilstaan bij de beloningscomponent. Het leidt geen twijfel dat beloningssystemen die niet op de goede manier gekoppeld zijn aan prestaties een corrumperende werking hebben. Evenzeer geldt dat als de beloning is gekoppeld aan kwantitatieve maatstaven, zonder dat daarbij ook aandacht aan de kwaliteit van de resultaten worden besteed. Een laatste kenmerk van slechte beloningssystemen is dat men geen rekening hoeft te houden met tegenvallers die zich later mogelijk voordoen. Anders gezegd: je houdt de bonus ook al blijkt er later sprake van forse tegenvallers door de geleverde prestaties.

Vaak kijkt men naar de bonussen van de financiële topmannen als illustratie van een slechte beloningsstructuur. Nu zijn die inderdaad, vooral in de Verenigde Staten duizelingwekkend hoog en staan ze niet in relatie tot de daadwerkelijk geleverde prestaties. Een voorbeeld: de totale beloning in de afgelopen vijf jaar van Richard Fuld, de topman van het inmiddels failliete Lehman Brothers, bedroeg bijna 270 miljoen dollar. In Europa liggen de salarissen beduidend lager, maar daar werden eveneens forse bedragen verdiend, met name door prestatiegerelateerde bonussen.

Wat men daarbij vergeet is dat ook het hoger en lager management in deze sector rijkelijk worden beloond met bonussen. Een gemiddelde analist op Wall Street kan op zijn vaste salaris van 250.000 dollar een even hoge bonus krijgen. Een handelaar kan op zijn basissalaris van 180.00o dollar zelfs een bonus krijgen van 5 miljoen dollar. De medewerkers van AIG-FP kregen per jaar allemaal een gemiddelde bonus van 1 miljoen dollar. De topman van AIG-FP, de heer Cassano, verdiende in acht jaar tijd zo'n 280 miljoen dollar (Committee on Oversight and Government Reform, Hearing AIG, 2008, p. 5, 97). Met dit bedrag verdiende hij als directeur van een werkmaatschappij overigens meer dan de topman van het moederbedrijf en ook meer dan de topmannen van Morgan Stanley, Goldman Sachs en Bank of America.

Gezien dit soort bedragen leidt het geen twijfel dat de druk om maar te verkopen of te presteren zeer groot was. Iedereen wist dat je met een paar jaar werken op Wall Street voor je hele leven binnen kon zijn. Dan wil je ook alleen maar verkopen en liefst zoveel mogelijk. Mocht het boven- dien later misgaan dan is dat helemaal niet erg, want dan zijn de schaapjes al lang op het droge.

Dit gedrag verklaart ook waarom een afdeling risicomanagement het in een financiële instelling zo moeilijk heeft. Het wijzen op mogelijke risico's betekent voor veel betrokken medewerkers en het management dat hun bonus in gevaar komt en zij zullen er alles aan doen de boodschapper van slecht nieuws buiten de deur te houden. Dit alleen al vanwege het feit dat degenen die geacht worden de onderneming te beschermen tegen onverantwoorde risico's door de beloningstructuur er juist toe worden aangezet om zich aan te sluiten bij de risiconemers.

Deze bonuscultuur werkt niet alleen negatief op het onderkennen en zelfs negeren van risico's maar kan ook risicozoekend gedrag en zelfs fraude in de hand werken. De fraudes bij Société Générale en Caisse d'Epargne zijn hiervan goede voorbeelden.

Voor wat betreft de Franse bank wist de handelaar Jérôme Kerviel ongemerkt een positie op te bouwen van 50 miljard euro en een daarop volgend verlies van 5 miljard euro te veroorzaken. Door onvoldoende direct toezicht en zwakke interne controlemaatregelen kon deze medewerker ongestoord zijn gang gaan. Het onderzoeksrapport meldt als belangrijkste tekortkomingen in de interne controle verder nog: onvoldoende controlemiddelen in verhouding tot de snelle groei in transacties, het ontbreken van cruciale geprogrammeerde controles op de ingenomen posities, en fragmentatie van controles over verschillende afdelingen (Société Générale, 2008a).

Uit het onderzoek van de interne accountantsdienst blijkt dat Kerviel met zijn fraude als enig doel had om zoveel mogelijk omzet te genereren teneinde zijn bonus te vergroten (Société Générale, 2008b).

Bij een soortgelijke fraude heeft een handelaar bij Caisse d'Epargne bewust de limieten op de handel in derivaten overschreden, dit leverde een schade op van 751 miljoen euro (De Tijd, 2008).

De financiële sector begint zich overigens wel degelijk te realiseren dat de bonusstructuur op de helling moet om verdere ongelukken te voorkomen. Als eerste komt de Zwitserse bank UBS met een nieuwe compensatieregeling die een voorbode kan zijn van veranderingen in de hele bancaire sector (UBS Compensation Report, 2008). Voortaan zal de bonus gebaseerd zijn op heldere prestatiecriteria die gekoppeld zijn aan de toegevoegde waarde op langere termijn. Daarnaast komt er een bonus/malus systeem waarbij een deel van de bonus in een depot blijft en moet worden teruggestort bij slechte resultaten.

Hiermee wordt expliciet erkend dat beloningstructuren 
waarbij de medewerker alleen maar wint, zonder verantwoordelijk te zijn voor de eventuele verliezen even schadelijk kunnen zijn als de exotische financiële constructies waarmee de bonussen werden verdiend.

\section{Toezicht: de rol van de commissarissen}

In de pers wordt veel geschreven over het tekort schieten van toezicht door overheidsinstanties als de Securities and Exchange Commission (SEC) of De Nederlandsche Bank. Er wordt echter niet of nauwelijks gesproken over de rol van de commissarissen als toezichthouder.

Op zich is dat vreemd, want naast het management wordt van commissarissen, met name de auditcommissie, toch verwacht dat zij toezicht houden op zaken als risicomanagement en interne beheersing.

$\mathrm{Er}$ is slechts weinig informatie over hun functioneren beschikbaar. Alleen in de hoorzitting van Lehman komt het functioneren van de commissarissen aan de orde. Nell Minow van The Corporate Libray zegt in haar getuigenis dat het bij veel commissarissen ontbrak aan de noodzakelijke financiële kennis om effectief toezicht te houden (Committee on Oversight and Government Reform, Hearing Lehman Brothers, 2008, testimony Nell Minow, p. 2). Daarnaast is een opvallend gegeven dat de Finance \& Risk Management Commissie van de commissarissen slechts twee per jaar bij elkaar gekomen is in $2006 \mathrm{en} 2007$. Haar conclusie is dat Lehman een Risk management commissie had die er niets van begreep en ook geen adequaat toezicht hield.

Een soortgelijk voorbeeld zien we ook bij deAuditcommissie van AIG. De accountant(s) hebben in deze commissie het nodige gesignaleerd en gemeld over de gang van zaken bij AIG Financial Products zonder dat er verder werk van werd gemaakt (AIG, 2007, p. 7).

Alhoewel niet onderzocht, zou het mij niet verbazen dat een soortgelijk beeld zich ook bij de andere financiële instellingen voordoet.

De conclusie kan dan ook geen andere zijn dat er sprake is geweest van onvoldoende toezicht door commissarissen op de door het management gevoerde strategie die uiteindelijk heeft geleid tot het nemen van onverantwoorde risico's.

\section{Conclusie}

Het risicomanagement van financiële instellingen is duidelijk tekort geschoten, vooral voor de nieuwe financiële innovaties en dat juist in een categorie ondernemingen waar risicobeheer al van oudsher een van de kerncompetenties is.

De sterke groei in nieuwe financiële producten zoals derivaten en de enorme vlucht van het securitiseren van onderliggende activa hebben het risicobeheer ongetwijfeld bemoeilijkt door de specifiek benodigde kennis maar dat is geen enkel excuus voor het verantwoordelijke manage- ment en commissarissen. Eenvoudig geformuleerd: wat je niet begrijpt moet je gewoon niet verkopen.

Koppelen we de financiële innovatie aan een beloningsstructuur die de medewerkers aanspoort tot het nemen van onverantwoorde risico's dan komt er onherroepelijk een situatie waarin de financiële massavernietigingswapens hun vernietigende werking kunnen uitoefenen.

Op papier werd er misschien wel voldaan aan de nieuwe regelgeving op het gebied van interne controle en beheersing, maar de vraag blijft of dat in de praktijk ook wel effectief heeft gewerkt.

De ongelofelijk hoge verliezen die zijn geleden tonen dat in ieder geval zeker niet aan.

Het is daarom beter te spreken over de kredietschandalen dan over de kredietcrisis.

We moeten niet langer een eufemisme als 'financiële tsunami' gebruiken alsof alle ellende een natuurramp is waar niemand wat aan kon doen.

De financiële sector heeft het allemaal zelf over zich afgeroepen door onverantwoord en slecht management, waarbij rendement boven risico werd gesteld.

Dat daarbij in het jaarverslag ten onrechte een 'in control'verklaring werd gegeven door de directie is al even mysterieus en verbazingwekkend als de onvoorstelbare grote verliezen die tot nu toe geleden zijn in de financiële sector.
Prof. Dr. R. A. M. Pruijm RA is emeritus hoogleraar Administratieve Techniek aan de Erasmus Universiteit Rotterdam, zelfstandig adviseur, interim-manager en commissaris van ondernemingen. Hij heeft zich gespecialiseerd in Corporate Governance. Sinds 2007 is hij deeltijdlector Corporate Governance aan de Fontys Hogeschool te Eindhoven. 


\section{Literatuur}

- AIG Annual Report 2007.

- Committee on Oversight and Government Reform (2008), Hearing Lehman Brothers Bankruptcy: Hearing on the causes and effects of the Lehman brothers bankruptcy, testimony of Nell Minow (6 oktober 2008); http://oversight.house.gov/hearings.asp. - Committee on Oversight and Government Reform (2008), Hearing AIG bailout: Hearing on the causes and effects of the AIG bailout, Preliminary hearing transcript (7 oktober 2008); http://oversight.house.gov/hearings.asp.

- Committee on Oversight and Government Reform (2008), Hearing on Collapse of Fannie Mae and Freddie Mac, Preliminary hearing transcript (9 december 2008); http://oversight.house.gov/hearings.asp. - COSO (1992/1994), Committee on Sponsoring Organizations of the National Commission on Fraudulent Financial Reporting (Treadway Committee), Internal Control: Integrated Framework; zie: www.cpa2biz.com; www.snai.edu/cn/service/ library/book/0-Framework-final.pdf.

- COSO (2009). Committee on Sponsoring Organizations of the National Commission on
Fraudulent Financial Reporting (Treadway Committee), Guidance on Monitoring Internal Control Systems; zie: www.coso.org.

- Credit Suisse. Annual Report 2007.

- Dash, E. en J. Creswell (2008), Citigroup saw no red flags even as it made bolder bets, The New York times, November 23, 2008.

- De Tijd (2008), Trader Caisse d'Epargne in voorhechtenis, 29 december 2008.

- International Monetary Fund (2009), Global Financial Stability Report GFSR Market Update IMF, January 28, 2009.

- Pruijm, R.A..M. (2003), Behoorlijk ondernemingsbestuur: Lessen uit de boekhoudschandalen, Assen: Koninklijke Van Gorcum Uitgeverijen.

- Smeulders, F., J.A.H. Hillenga en S. Krishnan (2009), Kredietcrisis en de interne beheersing bij verzekeraars, Maandblad voor Accountancy en Bedrijfseconomie, jg. 83, no. 6 (dit themanummer).

- Société Générale (2008a), Report of the Board of directors to the General Shareholders Meeting, 22 mei 2008;

http://www.sp.socgen.com/sdp/sdp.nsf/V3ID/ C54C92B634428055C1257452005A7F61/\$fi le/report\%20part\%201.pdf.

- Société Générale. General Inspection Department. Mission Green (20 mei 2008); http://www.socgen.com/sg/file/fichierig/ documentIG_5197/rapportmissiongreen.pdf. - SFBC-UBS Subprime Report (2008), Subprime crisis: SFBC investigation into the causes of the write-downs of UBS AG, 30 september 2008; http://www.finma.ch/archiv/ ebk/e/publik/medienmit/20081016/ubssubprime-bericht-ebk-e.pdf.

- Sterngold, J. (2008), Journal of a plague:

Faith in markets cracks under losses, Bloomberg.com, December 31, 2008.

- UBS Compensation Report (2008): UBS's new compensation model, 17 november 2008; http://www.ubs.com/1/e/investors/ compensationreport.html.

- Vink, D. (2009), Securitisatie: hoe nu verder?, Maandblad voor Accountancy en Bedrijfseconomie, jg. 83, no. 6

(dit themanummer).

- Verbond van Verzekeraars (2009), Bouwen aan een meer crisisbestendige verzekeringssector in Nederland: Lessen uit de kredietcrisis, januari 2009. 